HUMAN SACRIFICE IN BALI: SOURCES, NOTES, AND COMMENTARY

Alfons van der Kraan

\title{
Introduction
}

Visitors to Bali who have had the opportunity to witness a cremation ceremony will be aware that it is a truly extraordinary pageant. The huge crowd of spectators, the elaborately decorated bamboo pyramid (bade), the long procession, the chanting priests (pedanda), the music of the gamelan, the funeral pyre, all this and more, make for an extremely colorful spectacle. Today's ceremony, however, traditional though it is in most respects, is no longer identical to that staged in precolonial times. The most important difference is that, in the contemporary ceremony, the custom of sacrificing one or more women, a custom the Balinese called mesatia (loyalty), 1 has been replaced by the more humane practice of burning a number of straw puppets. 2

The origin of the Balinese custom of sacrificing women at cremation ceremonies is a matter of conjecture. It may have been brought to Bali from India, via Java, along with other Hindu cultural and religious practices. It is possible also that mesatia developed as an indigenous Balinese custom which was later given a Hindu religious veneer. But whatever its origins, mesatia undoubtedly has been practiced in Bali for many centuries continuing right up to the time the island was colonized by the Dutch. And, just as Bali was colonized in stages, mesatia, too, was abolished in stages. Women were sacrified in North Bali (the principalities Buleleng and Jembrana) until the mid-nineteenth century, in East Bali (Karangasem) and among the Balinese population of Lombok until the late nineteenth century, and in Central and South Bali (Bangli, Tabanan, Mengwi, Gianyar, Badong, and Klungkung) until the early twentieth century. The last documented case of mesatia occurred in 1903 when two women were sacrificed at the cremation of Raja Ngurah Agung of Tabanan. 3

Although death is not in itself remarkable, there is unquestionably something terrifying, something chilling, about the planned, deliberate, and ritualistic taking of human life. Small wonder, then, that the handful of Europeans who witnessed the traditional Balinese cremation ceremony were deeply impressed

1. According to the nineteenth century German Orientalist Friederich, the term mesatia is derived from the Sanskrit satiswati which denotes a person who is truthful, loyal, and faithful. R. T. Friederich, "Voorloopig Verslag van het Eiland Bali," Verhandelingen van het Bataviaasch Genootschap voor Kunsten en Wetenschappen (hereafter VBG) 23 (1850): 10.

2. H. H. Juynboll, "Een Deensch bericht over eene vorstelijke lijkverbranding op Bali in het midden der 19e eeuw," Indische Gids 49 (1927): 232.

3. H. van Kol, Driemaal dwars door Sumatra en Zwerftochten door Bali (Rotterdam: Brusse, 1914), pp. 323-24. 


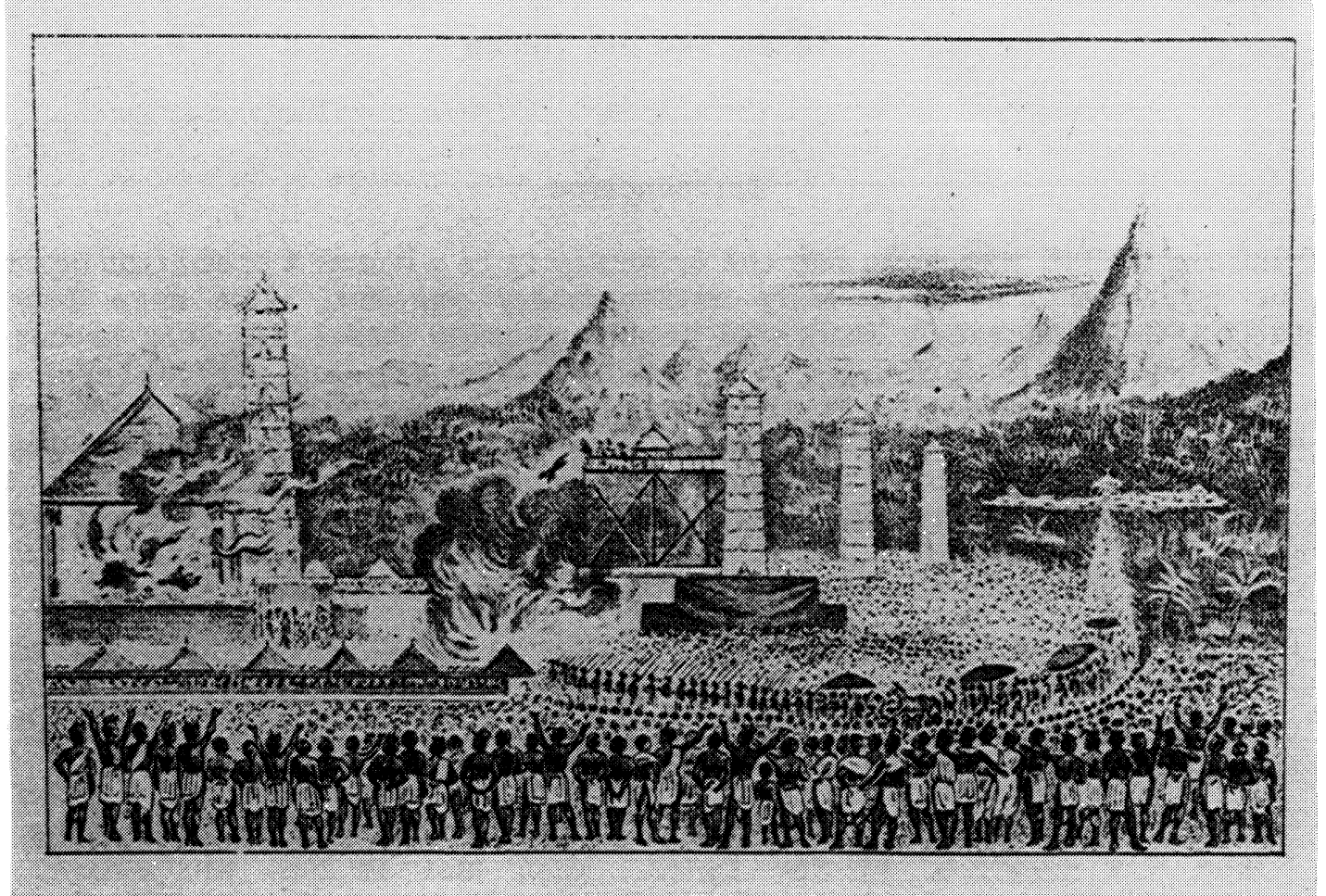

FICTIONAL REPRESENTATION OF MESATIA BASED ON THE ACCOUNT BY HELMS 
by it. Even the somewhat dour, businesslike D. B. Schuurman, Agent of the Dutch Trading Corporation (NHM), was not totally unaffected by the spectacle. Schuurman lived in Bali (Kuta) for fifteen months, from July 1839 to October 1840, and was present at the funeral of Raja Pamacutan, who was cremated in the town of Badong (Den Pasar) along with two of his female relatives who had died some time earlier: 4 "The cremation was held on 6 September [1840].... I will refrain from giving an account of the ceremony, although I must admit that a description of this kind could be a highly valuable contribution to the knowledge of this in many respects most remarkable people. Let it suffice to say that the festivities did full justice to the lengthy and costly preparations which had preceded them and that the ceremony was in every respect extraordinary. The most interesting aspect was the self-sacrifice of a young woman who, driven by religious zeal and watched by thousands of spectators, threw herself from a considerable height into a fierce blaze in order in this manner to join her Lord and Master in death." 5

Fortunately, not all European observers neglected to describe the Balinese cremation ceremony. In all, at least five such descriptions have come down to us, namely those by Oosterwijek (1633), Dubois (1829), Zollinger (1846), Helms (1847), and Friederich (1847). These eyewitness accounts allow us to "travel through time and space" and witness through the senses, consciousness, and literary ability of observers long since deceased, a spectacle which was without doubt the most elaborate, most grandiose ceremony in traditional Bali. The accounts also permit us to form a better idea of the real meaning of mesatia and they lay to rest a number of widespread misconceptions. The texts will show, among other things, that mesatia was not practiced by all Balinese, that it did not equal "widow-burning," and that the sacrifices were not genuinely voluntary. With the exception of the account by Helms, who wrote in English, the following descriptions have been translated, from the Dutch, for Oosterwijck, Zollinger, and Friederich, and from the French for Dubois.

\section{The Sources}

\section{A. Oosterwijck (1633)}

Jan Oosterwijck was a Chief Merchant (Opperkoopman) in the service of the Dutch East India Company (VOC). In February 1633 the then Governor-General, Hendrik Brouwer, sent him on a mission to Bali in an attempt to persuade the King (Susuhunan) of that island ${ }^{6}$ to undertake a military campaign against the

4. There is no suggestion in Schuurman's report that these female relatives of Raja Pamacutan had been sacrificed specifically for his cremation. Therefore, this was not a case similar to the one described by Zollinger (see below). There is every reason to believe that these two princesses (vorstinnen) had died of natural causes and that their bodies had been kept until the death of the Raja warranted the great expense of an elaborate cremation ceremony.

5. D. B. Schuurman, "Verslag van den Agent van de Factorij der Nederlandsche Handelsmij" (1840) in NHM Archief 9466 (The Hague, Algemeen Rijksarchief).

6. In Oosterwijck's report there is no indication at all that early seventeenth century Bali was politically fragmented. In fact, the political situation he outlines is identical to the picture drawn in 1597 by Aernoudt Lintgensz, the first Dutch sailor to set foot in Bali. See Aernoudt Lintgensz, "Bali 
Javanese Kingdom of Mataram with which the VOC was at war. The Governor-General was very much in need of an ally. Although the Company had gained a foothold in Java when it established the fortified settlement of Batavia (1619), its territorial power did not as yet extend very far beyond the walls of that fortress. Mataram remained a formidable adversary, an adversary which only four years earlier (1629) had laid siege to Batavia, and which, it was feared, might at any time stage another attack. Brouwer, acutely aware of these dangers, instructed his envoy to do everything in his power to convince the $\mathrm{King}$ of Bali that an anti-Mataram alliance with the VOC would be much to his advantage. Oosterwijck was to present the King with a fine Persian horse, a barrel of Spanish wine, a gilded chair, and various other gifts, and was to hold out the promise that, should the King agree to send an army to Java, the Company would provide naval protection and supply the Balinese army with rice for the duration of the campaign. In addition, Oosterwijck was to tell the King that the Company made no claim to any territorial gains which might result from the expedition. 7

Oosterwijck's mission, however, was not a success. In late February 1633 he arrived on the roads of Panarukan on Bali's north coast, where he waited almost two weeks before an official Balinese delegation boarded his ship and inquired into the purpose of his visit. After receiving permission to proceed to the Balinese court at Gelgel (near present day Klungkung), Oosterwijck sailed to Couterawas (?) on Bali's east coast where he arrived on March 12. The following day the Dutch envoy and his party were taken to Gelgel in stately procession. At Gelgel, Oosterwijck was again forced to exercise patience. He only received final word towards the end of March when four high-ranking Balinese officials (punggawa) told him that, wishing to live in peace with Mataram as well as with the Company, the King had no need of the Company's assistance. Although Oosterwijck did have a meeting with the Crown Prince, Panarackan Patickan, whom he presented with the Governor-General's gifts, all his attempts to be received in audience by the King himself proved fruitless. He was told that the King was totally preoccupied with the recent death of two of his sons and of his mother and that he refused to see anyone. 8 Apparently this was not just a diplomatic ruse, because on March 21 and 22, 1633 Oosterwijck did in fact witness the cremation of the King's mother:

The same day, about noon, the Queen's body was burnt outside the city with twenty-two of her female slaves. ... The body was carried out of the house through a large hole which had been made in the wall on the right hand side of the gate. This was done to avoid meeting the devil; the dead are never taken out through the proper doors because the devil knows precisely where they are. 9

1597," Bijdragen van het Instituut voor Taal-, Land- en Volkenkunde (hereafter BKI) 5 (1856): 203-32; and P. A. Leupe, "Het Gezantschap naar Bali onder den Gouverneur-Generaal Hendrik Brouwer in 1633," ibid., pp. 1-71. Both observers testify that Bali was a unified realm ruled by Kings of the Gelgel dynasty.

7. Ibid., pp. 1-71.

8. Ibid.

9. This quaint explanation tells us more about Oosterwijck's religious beliefs than about those of the Balinese. It may serve to remind us, however, that the devil was very real to Europeans of the seventeenth century. 
The female slaves destined to accompany the deceased on her journey to Heaven went before, according to their ranks, those of the lowest ranks taking the lead, each supported from behind by an old woman, and carried on a pyramid [bade], skilfully constructed of bamboo and decorated all over with flowers. Before them were placed a roast pig, some rice, some betel and other knick-knacks as offerings to their God and thus they were carried in good order and in triumph to the sounds of drums and gongs [gamelan] to the place where they were to be executed and consumed by fire. At this place each found a kind of scaffold prepared for her, almost in the form of a trough, raised upon four short posts and edged on two sides with planks. After moving three times round in a circle at the same pace at which they arrived, and still sitting on their bamboo pyramids, they were taken from their vehicles one after another and placed in their respective troughs. Presently five men and two or three wom en approached each of them and, standing outside the troughs, they took away all the flowers and ornaments with which they were adorned. In the meantime the condemned made their offerings. Holding their joined hands above their heads they briefly held aloft the siri and pinang which the women posted behind them placed there, before throwing these offerings onto the ground. Some of the attendants released doves to indicate that the souls were on the point of taking their flight to Heaven. Other attendants released live chickens.

When this had been done the slaves were divested of all their garments, except their white frock; and while four of the men seized the standing victim, two by the arms which they held out extended and two by the feet, the fifth prepared himself for the execution. This was all done without a blindfold.

Some of the most courageous demanded the kris themselves, which they received in the right hand, passing it into the left, after respectfully kissing the weapon. They wounded their right arms, sucked the blood which flowed from the wound, and stained their lips with it, making with the point of the finger a bloody mark on their foreheads. Then returning the kris to their executioners, they received a first stab between the false ribs and a second, from the shoulder downwards, in a slanting direction towards the heart. As soon as the throes of death were visible in the countenance, without a complaint escaping them, they were gently lowered to the ground and stripped of the last remnant of their dress so that they were left completely naked. The executioners receive as their reward two hundred and fifty pieces of copper money, each about five sols in value. After the execution, the nearest relations, or persons hired for the occasion, come and wash the bloody bodies and, having cleaned them sufficiently, they cover them with wood in such a manner that only the head is visible. They then apply fire to the piles and the bodies are consumed to ashes.

The women were already executed, and most of them in flames, when the body of the Queen arrived. She was borne on a most exquisite and graceful pyramid [bade] consisting of eleven stories and supported by a number of persons proportional to the rank of the deceased. Two women were seated at each side of the body, one holding an umbrella [payong] and the other a fan of purple horsehair to drive away the insects. Two priests [pedanda] preceded the pyramid 
in a cart, each holding in one hand a long rope attached to the pyramid with which, so they believe, they lead the deceased to Heaven. In the other hand the priests held little bells, while musicians in the procession made such a noise with gongs, tambours, flutes and other instruments that the whole ceremony had less the air of a funeral procession than of a joyous village festival.

When the tow er carrying the Queen's body had arrived at its destination it was set alight while the chair and couch, which had been used by the deceased in her lifetime, were also burned. The assistants then regaled themselves with a feast, while the musicians, without cessation, struck the ear with a tumultuous melody, which was not unpleasing. This continued until dusk. In the evening, when all the bodies had been burnt, the relatives of the executed women and the chiefs returned home after having left a guard for the protection of the bones.

The following day the bones of the Queen were collected and carried back to her former residence with a ceremony equal in pomp to that of the preceding day. The bones were taken into the house through the same hole in the wall that had been used to carry the body out. We were told that every day a number of vessels of silver, brass and earth, filled with water, accompanied by a band of musicians and pikemen, are carried to the bones. Those who bear these vessels are preceded by two young boys carrying green boughs marching in front of others carrying the mirror, the vest, the loose garment, the betel-box and other conveniences of the deceased. The bones are devoutly washed during a month and seven days, after which, they are again placed in an exquisite pyramid and taken in triumph to a place called Labee where they are entirely burnt. The ashes are carefully collected, placed in urns and taken some distance from the beach in the Queen's carriage. The urns are then cast into the sea and this terminates the ceremony.

We were informed that when a prince or princess of the royal family dies, his or her female slaves walk around the body crying loudly and eagerly soliciting to die with their master or mistress. The following day the King designates, one by one, those who are to be sacrificed. From that moment until they are burned, they are daily conducted, at an early hour, each in her vehicle, to the sound of drums and flutes, to their Gods outside the town to perform their devotions. Their feet are wrapped in white cloth for they are no longer permitted to touch the earth; they are considered as consecrated. The young women, little skilled in these religious exercises, are instructed in them by aged women who accompany them, and who, at the same time, confirm them in their resolution. The day and the night before the funeral the women are entertained with dances, songs, plays and music; they are not allowed to sleep. In order for them not to think about death or to fear death they are given drinks which render them half drunk and senseless.

No female slave, however, is forced to burn; they do it of their own free will. Yet, even those who have agreed to be sacrificed, and have not been accepted, as well as those who have not offered themselves, are alike locked up for the remainder of their lives, in a 
convent, without being permitted the sight of man. If anyone should find means to escape from her prison, and is afterwards taken, her fate is instantly decided; she is stabbed to death, dragged through the streets and her body cast to the dogs to be devoured. 10

At the funeral of the King's two sons who died not long ago, fortytwo women of the one and thirty-four of the other were stabbed and burnt. Women of royal blood, however, leap themselves into the flames, as did recently the principal wives of the two princes; these women regard themselves as too worthy to be touched by anyone. A kind of bridge is erected over the burning pit, which the women mount, holding a piece of paper close to their foreheads and having their robe tucked up under their arms. As soon as they feel the heat they precipitate themselves into the burning pit which is surrounded by a square palisade of tree trunks. In case their resolve should weaken at the appalling sight, a brother, or other near relative, will be on hand to push them in.

We were further told that the first wife of the younger of the two princes just alluded to, who was the daughter of the King's sister, asked her father, who was the prince of Couta [Kuta?], whether as she was but three months married, and on account of her extreme youth, she ought to devote herself on the funeral pyre of her husband. Her father, however, represented to her so strongly the disgrace she would, by preferring to live, bring upon herself and all her family, that the unfortunate young woman, summoning all her courage, leapt into the flames, which were already devouring the dead body of her husband. On the death of the reigning King no less than 120,130 to 140 women devote themselves to the flames. None of them are previously stabbed to death; irrespective of rank, they all jump into the fire of their own free will. 11

\section{B. Dubois (1829)}

Pierre Dubois (?-1839), a Netherlands-Indies official of French or Belgian (Walloon) extraction, was in all likelihood the son of J. A. Du Bois, the Assistant Resident of the Lampong Districts in South Sumatra. In 1821 Pierre Dubois worked as a junior clerk (third clerk of the second class!) in the Residency office of Krawang (Java). There he came to the attention of Resident H. A. van den Broeck, the same person who in 1817-18 had led a Dutch diplomatic mission to Bali in an unsuccessful attempt to persuade the Rajas of that island to acknowledge Netherlands-Indies sovereignty. 12 It was probably on Van den

10. Although this kind of family pressure certainly did play a role (see below, Conclusions), it is highly unlikely that women who refused to be sacrificed were treated in this manner. There never were any convents in Bali! Oosterwijck was either misinformed or he again superimposed a familiar European category upon an unfamiliar Balinese reality.

11. H. T. Colenbrander, Daghregister gehouden int Casteel Batavia vant passerende daar ter plaatse also over geheel Nederlandts-India. Anno 1631-34 (The Hague: Departement van Kolonien, 1898), pp. 176-84; J. Crawfurd, History of the Indian Archipelago, vol. 2 (Edinburgh: Constable, 1820), pp. 244-52.

12. H. A. van den Broeck, "Rapport nopens het Eiland Bali" (1821), in Collectie Schneither 131 (The Hague, Algemeen Rijksarchief). 
Broeck's recommendation that Dubois was chosen in 1827 for a very special assignment: to proceed to Bali in order to buy as many male slaves as possible for use as auxiliary troops in the Dutch colonial army, at that time (1825-30) hard-pressed in the war against Prince Dipanegara of Yogyakarta. 13

From April 1827 until May 1831, when he was recalled by Batavia, Dubois resided in Kuta in the South Balinese principality of Badong as the representative in Bali of the Netherlands-Indies Government. The Civil Commander, as Dubois was officially designated, lived in his Kuta establishment with a European doctor, who examined the "recruits" for physical fitness, a tough Sergeant-Major, and a detachment of twelve soldiers for security and for guard duties. In addition to purchasing about 1,000 to 1,200 slaves, 14 Dubois reported regularly to Batavia on social, economic, and political developments in Bali. These reports, which reveal him as an observant and highly intelligent person, are of the greatest interest. They contain a wealth of information on Bali in the late 1820s, information on such matters as the trade of Kuta, the institution of slavery, power relations among the lords of Badong, conflicts among the Rajas of Bali, and so on. 15 During his stay in Kuta, Dubois also wrote a number of private letters, in French, and addressed to an unknown person, in which he tried to describe and analyze Balinese society, culture, and religion. 16

Letter VIII in this collection is an eyewitness account of the cremation in 1829 of Gusti G'de Ngurah Pamacutan, one of the two ruling Rajas of Badong, at which seven women were sacrificed. 17 This account paints an extremely vivid picture of the ceremony. It is based on notes Dubois took while the ritual was in progress and was written immediately af terwards, when the impressions were still fresh in his mind. While Dubois certainly made no secret of his revulsion at the human sacrifices he witnessed, the distaste he felt for this

13. C. Lekkerkerker, "Het voorspel der vestiging van de Nederlandsche macht op Bali en Lombok," BKI 79 (1923): 211.

14. For a discussion of the structure of the Balinese slave trade, see A. van der Kraan, "Bali: Slavery and Slave Trade," in Slavery, Bondage and Dependency in Southeast Asia, ed. Anthony Reid (St. Lucia: University of Queensland Press, 1983), pp. 315-40.

15. Dubois' reports of July 5, 1829, of July 22, 1830, of February 27, 1831, and of March 15, 1835 are bundled in a single dossier (verbaal): V 8 Jan. 1857 No. 27 (The Hague, Algemeen Rijksarchief).

16. Ibid.

17. Although Dubois gives a very detailed description of the cremation ceremony, he fails to mention precisely how many women were sacrificed. However, the British missionary $W$. H. Medhurst, who briefly visited North Bali (Buleleng) in 1829, provides us with that piece of information. In his "Short Account of the Island Bali," which was published in the Singapore Chronicle of June 1830, Medhurst wrote: "A young Englishman who witnessed the burning of seven widows last year at Badong, told me, that the concourse of people was so great that he could not get very near: but he could observe the women seated on scaffolds about 10 or 12 feet high, combing their hair and apparently in a state of stupefaction, insensible to all around them." The young Englishman may have been a certain Tomlin who accompanied Medhurst on his visit to Bali. (Lekkerkerker, "Het Voorspel," p. 216.) If Tomlin was that observer, he almost certainly attended the ceremony with Dubois. (J. H. Moor, ed., Notices of the Indian Archipelago [London: Cass, 1837], p. 92.) 
practice did not affect the quality of his description. In fact, Dubois' account is not without literary merit. Written mostly in the present tense, his description places the reader in the midst of the unfolding spectacle:

\begin{abstract}
Dear Sir,............ l left you last evening with the promise to conduct you today to the place in the town of Badong [Den Pasar] consecrated to the celebration of funeral ceremonies. You are going to watch a ceremony of the greatest interest, a ceremony which concerns a prince of the highest rank [Gusti G'de Ngurah Pamacutan] and to which we have been invited by the Badong court. Thus, when you are ready to depart we will go and select a favorable vantage point on the square where the spectacle will take place. But first you must realize that this is the most august of the Brahman religious ceremonies seeing that the entire corps of Brahman priests, 18 with the Pedanda Agung [high priest] at its head, will be there in pontifical action.
\end{abstract}

You will learn that the place consecrated to the celebration of funeral ceremonies is located at the center of town where it has served this purpose since time immemorial. It is next to Kraton Pamacutan [the palace of Pamacutan], the residence of the head prince of the leading branch of the ruling family. 19 You will also learn, no doubt with pleasure, that we shall be accompanied by Gusti Made Oka, the youngest son of Gusti Ngurah Pamacutan. In a crowd like the one in which we will find ourselves, composed for the most part of strangers in the principality of Badong, some distressing misadventure could easily arise if we were not under royal protection. We had not expected protection but, apparently, the great prince [Raja Kassiman] knows how to behave in this respect. He realizes that he must protect the representatives of a power [i.e., the Netherlands-Indies Government] with which he has friendly and businesslike relations. He may also have wanted to compensate us for the circumstance that, due to certain religious rules, we are not allowed to approach his highness during the ceremony.

18. The priests (pedanda) were always recruited from among the ranks of the Brahmans (title: "Ida"), the highest of the three Balinese castes.

19. The ruling family in nineteenth century Badong was the House of Pamacutan. The founder of this dynasty was Gusti Ngurah Made Pamacutan who established Badong's independence from Mengwi in the early 1800s. Upon his death in 1813, his realm was divided among his three sons by aristocratic (triwangsa) wives: (A) Gusti G'de Pamacutan; (B) Gusti Made Pamacutan (also called: Raja Kassiman); and (C) Gusti Jambi. Prince (A) died in 1817 and was succeeded by (AA) Gusti G'de Ngurah Pamacutan, who was the son of his sister. The most forceful personality of princes (AA), (B), and (C) was (B), commonly called Raja Kassiman after the district in which he had his palace. In the 1810s Raja Kassiman gained ascendency over his half-brother (C) by means of a convenient dynastic marriage. And after the death and elaborate cremation in 1829 of (AA), the spectacle witnessed and described by Dubois, Raja Kassiman established supremacy also over that branch of the dynasty. After the death of (AA), Raja Kassiman moved his palace (puri) to Badong (Den Pasar). He was the protector of Dubois and later, in the late 1830s and in the 1840s, of Mads Lange. Raja Kassiman kept supreme power in Badong until his death in 1861 (Lekkerkerker, "Het Voorspel," pp. 207-8). 
Here we are the pagans, especially while the god Brahma is publicly exercising his office.

I must confess that, without knowing why, I feel a certain painful sensation, a sensation akin to regret. Perhaps it is because I agreed, out of kindness, to cast my eyes upon a tragedy bloodier than any the Greeks ever saw. Don't you have a similar feeling? If you wish we could excuse ourselves under a more or less plausible pretext.... and return home......But here is our Protector, our dear Made Oka! "Good day! - Tabeh! - Your Servant! Ada bach? Come along with me gentlemen!" - We are on our way; we have arrived; we take our place under a tree just outside the enclosure in which the tragic scene will be enacted.

"The great funeral ceremonies," says Made Oka, "always take place here in the capital [Den Pasar] where the princes, even those who on account of administrative duties are obliged to reside elsewhere, always maintain a palace [puri]. The lesser ceremonies, those in which there are no female self-sacrifices, take place in the villages; these ceremonies are the funerals of Gustis without vassals and those of the common people [sudra]. 20 As for the haughty Brahmans, their funeral ceremonies take place in the large market town of Intaran which is ruled by the Pedanda Agung of Badong.

"The cemetery on which we find ourselves is divided into three parts. Over there, on the eastern side, is the space reserved for the princes and other members of the high nobility. Here, in the middle, is the terrain assigned to the lower nobility. And over there, on the western side, is the space for the common people. The terrains reserved for the lower nobility and the common people are dotted with temporary graves, shaded by mourning trees. These graves are occupied by deceased of both sexes whose flesh has not yet returned to Buddha. The space assigned to the princes and high nobility is usually empty, because, as you already know, the remains of the princes are kept in their palaces until the day they must be delivered to the flames. If you pass by this cemetery in a few days you will see nothing but a heap of debris in the middle of that enclosure. This is all that will remain of the structures erected for this funeral because they will all be destroyed immediately after the ceremony. But at the moment you see other things there.

"At the center of the enclosure you see a pavilion of about twelve to fifteen feet square resting on a masonry of mudbricks. The height of the masonry depends on the rank in the royal world of the prince who is to be cremated. Today it is twelve feet high because they are going to burn the body of a prince of the highest rank. But the masonry is lower by two, four, and even six feet for princes one or several degrees inferior. It is lowest for princesses.

20. "Gusti" is the title of members of the third Balinese caste, the Wesiyas. Although most Rajas and princes belonged to this caste, there were also many poor Wesiyas who were not able to afford these expensive cremation ceremonies. The sudra, i.e., those who did not belong to one of the three castes, comprised the overwhelming majority of the population, some 92 percent. 
"The sides of the pavilion face the four cardinal points. As you can see, the sides are open; there are only four posts surmounted by a conical roof of thick linen cloth. Several small conduits are cut into the platform to drain the water and other liquids that will be spilled.

"In the center of the pavilion, on a stand of about three feet high, you see a wooden cask very skillfully sculptured and magnificently decorated. These casks are always in the shape of a great quadruped, either a lion, an elephant or a crocodile. For princesses they are in the shape of a white cow. The cask which we now behold and which, as I have just said, is for a prince of the highest rank, is in the shape of a red lion. This lion-shaped cask faces east and the lion's long mane stands on end in imitation of shooting flames. It has a lid with a handle formed by the lion's turned up tail. The bottom of the cask is pierced by about twenty small holes which allow the liquids to flow through.

"Right at the eastern side of the pavilion you see a kind of stairway or leaning bridge. This bridge stands at an angle of about forty-five degrees to the ground and it rises towards the East to a perpendicular height of more than one hundred feet. The bridge is about four feet wide and is made of bamboo and rattan. It is held up by two rows of cacao-tree trunks which are positioned along its entire length at intervals of twelve to fifteen feet. But even though these trees reach a gigantic height in Bali, there are none which attain the required elevation to furnish the posts for the highest section of the bridge. To solve this problem they had to have recourse to expedients: they contrived to make, with bamboo, rattan, and much art, a contraption for support which deserves to be classed among the bold and ingenious conceptions. There is a screen along the entire bridge furnished every eighteen inches or so with projecting crosspieces which assure the steps of those who must climb and descend it. The hand-rails of about three feet in height prevent people from falling sideways. Finally, we see on the level space at the top of the bridge, a little house made very pretty with gilting, festoons, and bouquets. The posts, the screen, and the hand-rails of the bridge are all embellished by tufts of green-leaved branches, and that with such profusion that it is difficult to distinguish the different parts of the bridge. Thus, the total structure is agreeable to the eye.

"Let us now," continued Made Oka, "look to the South of the pavilion. There we see, at a distance of about one hundred paces, a row of structures similar to the one I have just described, that is, leaning bridges with little houses on top. There are, however, a few differences. These structures are no higher than about fifty or sixty feet; the level spaces on which the little houses stand are longer by about fifteen faet and in front of the high side of each of these bridges there is a blazing pit.

"Like the pavilion, these pits are constructed of mudbrick. They consist of a circular wall of about three to four feet in height, surrounded by a row of upright banana-tree trunks. The pits are about ten feet in diameter. We note in addition that a very thick screen of bamboo, about ten feet wide, drops down from the end 
of each level bridge to the edge of the pit. This serves to protect the bridge from the flames.

"Now we look to the North of the pavilion. The structures you see there are the stands reserved for the princes of the royal family, their spouses of honor [i.e., legal wives], and their daughters. But what is the matter - are you surprised?" - Yes, it is true, I am surprised. My soul cannot comprehend how it is possible that women are capable of beholding scenes as tragic as those which are about to take place. - "Nonsense!" replied Made Oka. "It is not just Balinese princesses who like to watch these heroic scenes; common women are also interested. We are already surrounded by hundreds of common females; there are people on all sides and even up the trees; they are arriving continually and more are still to come. And this is not surprising because is there a more magnificent spectacle in the world than that of a soul ascending in triumph to Heaven?

"While we are waiting for the funeral ceremony to commence we might go and examine at close hand these different constructions so that you may one day tell the people of your country what the Balinese do to honor the souls of their fathers."

Take note, please Sir, of this infernal walk! Nothing can be more savage than this funeral circle filled with burning pits, fueled by characters of such ferocious appearance that they could easily be mistaken for devils. Note, I say, that the inspection we have just completed has not produced any other effect upon me than to sadden my spirits, because everywhere I looked I saw preparations, invented by deceit and superstition, to commit fanatical murders with impunity.

"Well, Gentlemen," continued Made Oka, "it will not be long now before you will see something that will arouse your greatest admiration. Let us resume our place under our tree for it is already eleven o'clock. You can hear pious chants and the sounds of cannon, muskets, and gamelan coming from the direction of the palace. This means that something is about to happen.

"A pyramid [bade] of about forty feet in height appears. It is artistically constructed of bamboo; it is open work and is elaborately ornamented with decorations, festoons and rosettes of colored paper. The pyramid consists of three stories, and on the top story two women can be seen.

"Carried on the shoulders of about forty or fifty men the pyramid moves towards the enclosure. It is preceded by a half-company of infantry and is followed by a procession of women carrying vases or baskets on their heads. The pyramid is accompanied by a group of men carrying a long ladder.

"Upon entering the enclosure the procession moves in the direction of the first pit structure, situated just South of the pavilion. The procession walks around this first structure twice and then stops at the foot of its bridge, where the pyramid is put down. Four strong fellows take the ladder and place it against the pyramid. They climb it, they take the two women on the top story in their arms, carry them down the ladder and up the bridge to the little 


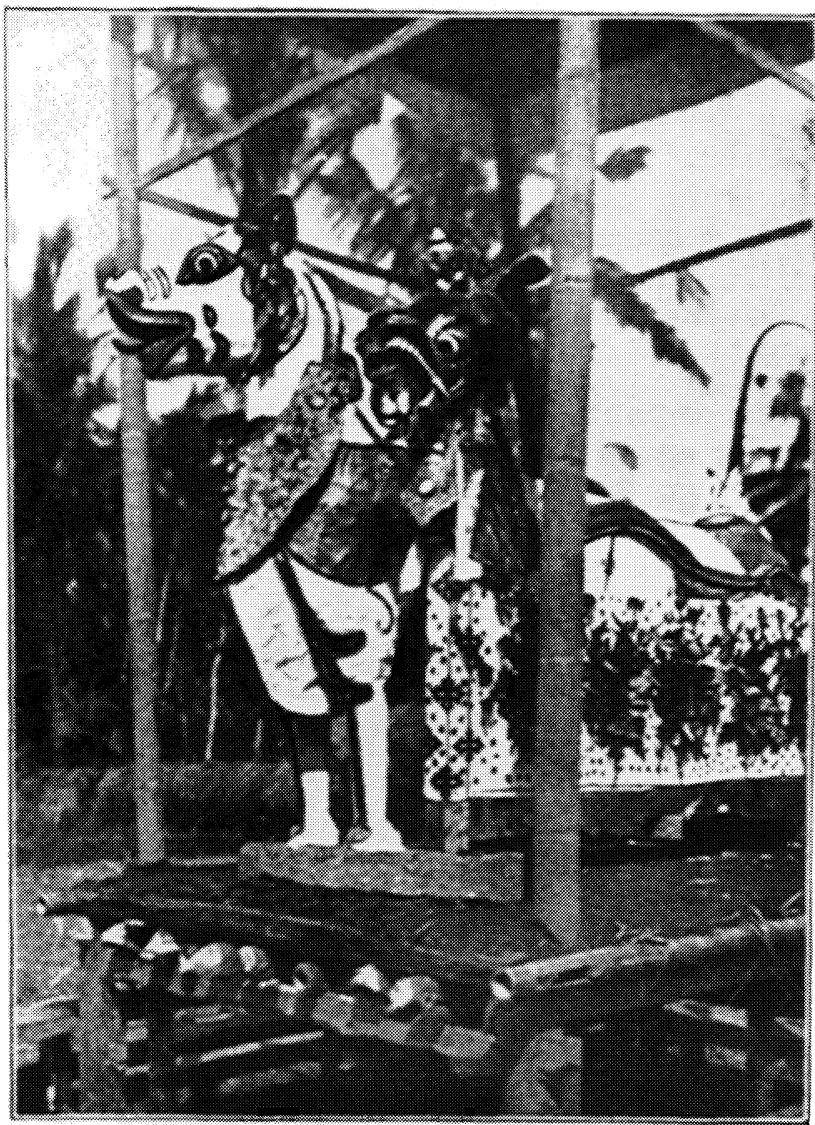

AN OX-SHAPED CASK IN WHICH THE BODY IS CREMATED (1920's)

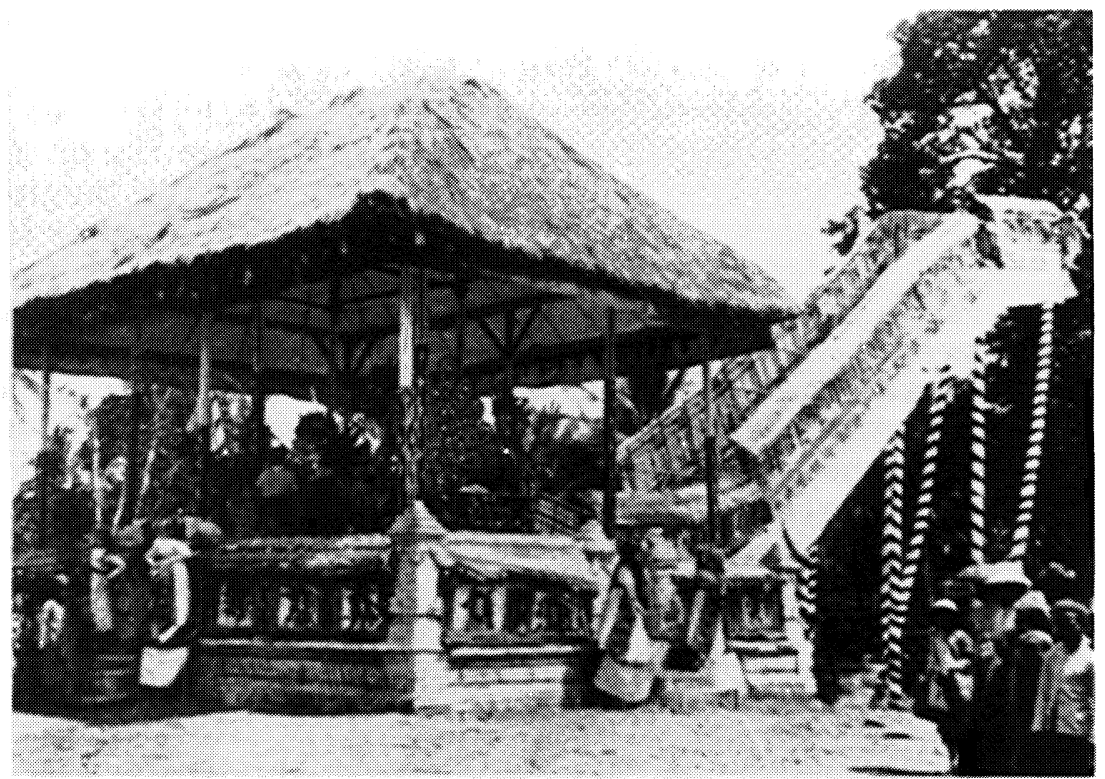

PAVILION AND BRIDGE ALONG WHICH THE BODY IS BROUGHT DOWN FROM THE PYRAMID (BADE) (1920'S) 
house on top. One of the women is the first Bela. 21 She was carried by her father, her brother, or other close relative. The other woman is a Manko [Pamanko?]; she accompanies the Bela and directs her actions up to her last moment. A number of men and women climb after them and sit down in the little house; they are the mother, the sisters, the brothers, the aunts, the uncles, and other close relatives of the Bela.

"The chants and the sounds which accompanied the procession have ceased. But now we hear these sounds again heralding the approach of another procession carrying the second Bela. The same ceremony occurs, and the Bela is introduced into her little house with a party similar to that of the preceding Bela. The other Belas arrive one after another and after identical formalities each is deposited separately in her little house. Only the last one has no leaning bridge prepared for her. The reason is that all Belas have the right to choose the method of death and this one elected to die by means of a kris-thrust to the heart.

"While these preparations to the funeral were in progress they did not neglect to fire the pits and at this moment they contain a good three to four feet of glowing embers. The heat which the pits throw up, combined with the heat of the sun and that of the multitude of spectators is enough to suffocate us."

Speaking of the pits, do you hear, Sir, the dull, lugubrious noise produced by the escaping masses of flames coming into contact with the air? And don't you agree that this hellish noise appropriately symbolizes the present occasion?

"It is noon!" exclaims Made Oka. "The chants and the sounds of cannon, muskets, and gamelan have started up again louder than ever. Over there we see, slowly approaching, the top of a new pyramid towering above the tallest trees. Like the other pyramids, this one, too, is constructed of open work bamboo. At the base it measures about thirty feet square and at the top about eight feet; it consists of eleven stories and is over one hundred feet high. The pyramid is pompously decorated; the different compartments glitter with the most vivid colors and the moving ornaments made of silk fabrics and netting are set against a background of colored and gilded paper. The garlands, the ribbon rosettes, and the fringes, which are artistically utilized to identify each story, sway with the movement of the porters. It seems as if an enormous tortoise is carrying the pyramid along its path, but in fact it is being carried on the shoulders of over four hundred men. Now that the pyramid is near we perceive on the top story a personage of importance sitting next to a kind of chest: it is the Pedanda Agung sitting next to the royal coffin.

21. According to Friederich, the term "Bela," which is derived from the Sanskrit "wela" (sudden and easy death), refers to a woman who at the cremation of her husband or master jumps alive into a blazing pit. The term, he claims, is also used to denote all those men, women, and children, who elect to die with their lord in a mass suicide attack (puputan) (Friederich, "Voorlopig Verslag," p. 10). 
"This gigantic pyramid is preceded by a large battalion of troops armed with pikes and muskets. The men are naked from the soles of their feet to their breast except for a small white band of cloth. This band circles their loins and is tied at the front; the ends are turned back between the legs and are reattached to the band at the back. Although this loincloth only barely hides their sex and leaves uncovered their buttocks and thighs, the men are nevertheless dressed in sleeveless red jackets which only reach to the nipples. Their head is adorned with a band of white cloth which leaves the top of the head uncovered. But since the men have cut their hair short in honor of the dead prince, the headband does not produce a pretty effect: it pushes up the hair like a straight, stiff brush. The officers, who are all the sons of Gustis, are similarly attired, except that their little jackets are of green velvet. And finally, they all carry a kris on the back.

"Between this battalion and the pyramid marches a large group of Brahmans, also martially attired, for in Bali every man is a warrior. They are completely naked except for the aforementioned band of white material which hides two inches of their loins as well as their manly jewel (bijou viril). They wear neither the jacket nor the headband of the $m e n$ in the battalion, but they do carry an impressive-looking kris on the back. The Pedanda Agung and all the other priests who take part in the ceremony are dressed in the same way.

"Immediately behind the pyramid march the old officials and followers of the deceased prince. The procession is closed by a band of three to four hundred women, each carrying on her head a vase or basket containing the ingredients the Pedanda Agung will use in his treatment of the royal bones. The pyramid is placed against the upper part of the leaning bridge next to the pavilion. Several priests climb the bridge and join the Pedanda Agung on top of the pyramid. They help him move the royal bones from the precious coffin in which they lie into a less valuable coffin, and then they carry the latter coffin from the top of the pyramid to the little house on top of the bridge. When everyone has fulfilled this duty the procession breaks up allowing all participants to take up their assigned positions.

"Now that the exalted company is seated and the sounds which accompanied the royal procession have died down, the Brahman priests spread two very long pieces of new white linen cloth along the ramps of the great bridge. These pieces of eloth have been formed by joining together about half-a-dozen ordinary pieces. Escorted by the Pedanda Agung and carried on the shoulders of four priests, the royal coffin descends to the foot of the bridge. Then the priests spread the two pieces of linen cloth around the pavilion, leaving just enough space between them to allow for the passage of a procession. The coffin is placed on a pretty palanquin and escorted by the Pedanda Agung and, borne by the same four priests, it is carried twice around the pavilion. The coffin is then deposited inside the lion-shaped cask, and the Pedanda Agung begins his ritual.

"Excuse me, Gentlemen!" says Made Oka. "They are calling me to the stand of the great prince. I will leave you for a few minutes 
but my assistant here will stay with you. I will return to take you to dinner."

My word, Sir, I will myself take note of what is to come.

The Pedanda Agung is in the pavilion busily manipulating the royal bones inside the cask. He is surrounded by a dozen or so of his principal priests, while the other priests stand around the pavilion. All the pots and vases carried by the band of women which followed the great pyramid are one by one handed to the Pedanda Agung. He pours their contents into the cask, praying loudly. Each time he empties a pot or vase he throws it over the heads of the priests out of the pavilion onto the ground, where it shatters into a hundred pieces. This operation, which takes place while the audience maintains the most profound silence, is very lengthy because there are at least three hundred pots and vases to be emptied. But at last the operation is completed and the lid is placed onto the lion-shaped cask.

Half a dozen Brahman priests now take hold of some long torches of fine wood. They gallop to the nearest burning pit, light them and bring them back to the Pedanda Agung who placed them under the lion's belly. A heap of these torches is there at his disposal so that he may keep a bright fire going for the duration of the scene which is to follow.

As soon as flames appear in the pavilion, the Bela who occupies the right-hand position in the row of pit-structures, comes out of her little house. She is dressed in white from the bosom to the knees, while her hair, curiously arranged, is decorated with flowers. Her relatives and the Manko are squatting along the ramps of the small horizontal bridge. While she advances slowly they encourage her to sustain her part nobly. The Bela begins a trance-like dance (tandak); a profound silence reigns and one hears nothing but the sinister murmur of the blazing pits. After about ten minutes she arrives half-way across her bridge where there is a door. While the Bela is in the doorway a turtledove, which had been tied to it with a piece of string, is cut loose by the Manko and flies away up into the sky. At that moment the acclamations of a hundred thousand Stentors burst forth from all sides; it is the signal that the self-sacrifice has been approved by the Gods.

Each month there is a short period during which a woman who has not yet arrived at her menopause cannot, according to the laws of nature, approach her husband. If then this circumstance, which may very well be provoked by fear, is apparent to the Manko when she conducts a secret examination, the turtledove is not cut loose and the self-sacrifice is not performed. The Bela, who is to occupy a place among the Gods, must arrive in Heaven as pure as an angel. If this circumstance should prevail, she returns to the terrestrial world, without any unpleasant consequence for such is the will of Heaven.

When the bravos have ceased, the Bela continues her way. She now walks a plank which extends to the end of her bridg e.....most of the audience intones funeral chants....the Bela loosens her hair and lets it fall over her shoulders....they tie her skirt [sarong] over 
her knees.....she resumes her trance-like dance.... her father hands her his kris with which she wounds her arm and shoulder.... with the tip of the kris she draws blood from the wounds and she reddens her forehead. This act is intended to show her relatives, who are encouraging her to persevere, that she does not fear death. The Bela joins in the pious chants she hears around her....she arrives at the fatal edge of her plank....she returns the kris to her father and clasping her hands together over her chest, she falls straight, appears for one second in the air, and is engulfed in the pit of embers which awaited her. A dozen men, positioned around the pit, watching for this moment, armed with fagots and long bamboos full of oil, throw them over her. How the noisy acclamations of the multitude bless her happy destiny! How a great column of black smoke shoots up into the air!

During her journey on the bridge and over the plank one did not perceive any sign of fear or repugnance. On the contrary, her face bore the mark of serenity and of ecstatic anticipation. Nevertheless, not all of them are endowed with such intrepid courage. There are those who, on arriving at the edge of eternity, feeling the hot air and seeing the fiery pit below, lose courage and hesitate to take their last step. But then their father or their brother, who has been holding the other end of the plank lifts it.... and....the last step is taken.

Well, Sir, haven't you seen enough? Let us escape as quickly as possible for we are in a place too hateful for us to stay any longer. But there is no way out of here. The crowd has blocked all the exits, making it necessary for us to watch this cruel tragedy until the final act.

Five minutes after this scene, when the loud acclamations of the multitude have ceased, the second Bela comes out of her little house. She goes through more or less the same motions as the first....the turtledove flies away.... and the outcome is the same. Each little house, bridge, and pit in turn present a similar triumphal catastrophe until the last Bela has fallen. There is but one exception. One of the women had chosen to die by means of a kristhrust to the heart and for her sacrifice a little house had been prepared on the ground with a pit to the side. When it is her turn, she comes out of her little house; she is surrounded by her closest relatives, and receives the kris from her father with which she at once runs herself through straight down from the top of her left shoulder. She falls whereupon her father and her brother lift her up and throw her all throbbing into the blazing fire. 22 This scene was not the least hideous of the piece.

A particularly heart-rending sight was that of an old, white-haired woman among the Belas. It took her less than four seconds to complete her journey over the bridge; she took three great leaps

22. Here Dubois describes the sacrifice of a Satia. Whereas the term "Bela" refers to a woman who jumps alive into a blazing pit, the term "Satia" denotes a woman who runs herself through before being cast into the fire. According to Friederich, the Satia-type sacrifice, while comparatively rare, was regarded as the most noble (Friederich, "Voorlopig Verslag," p. 10). 


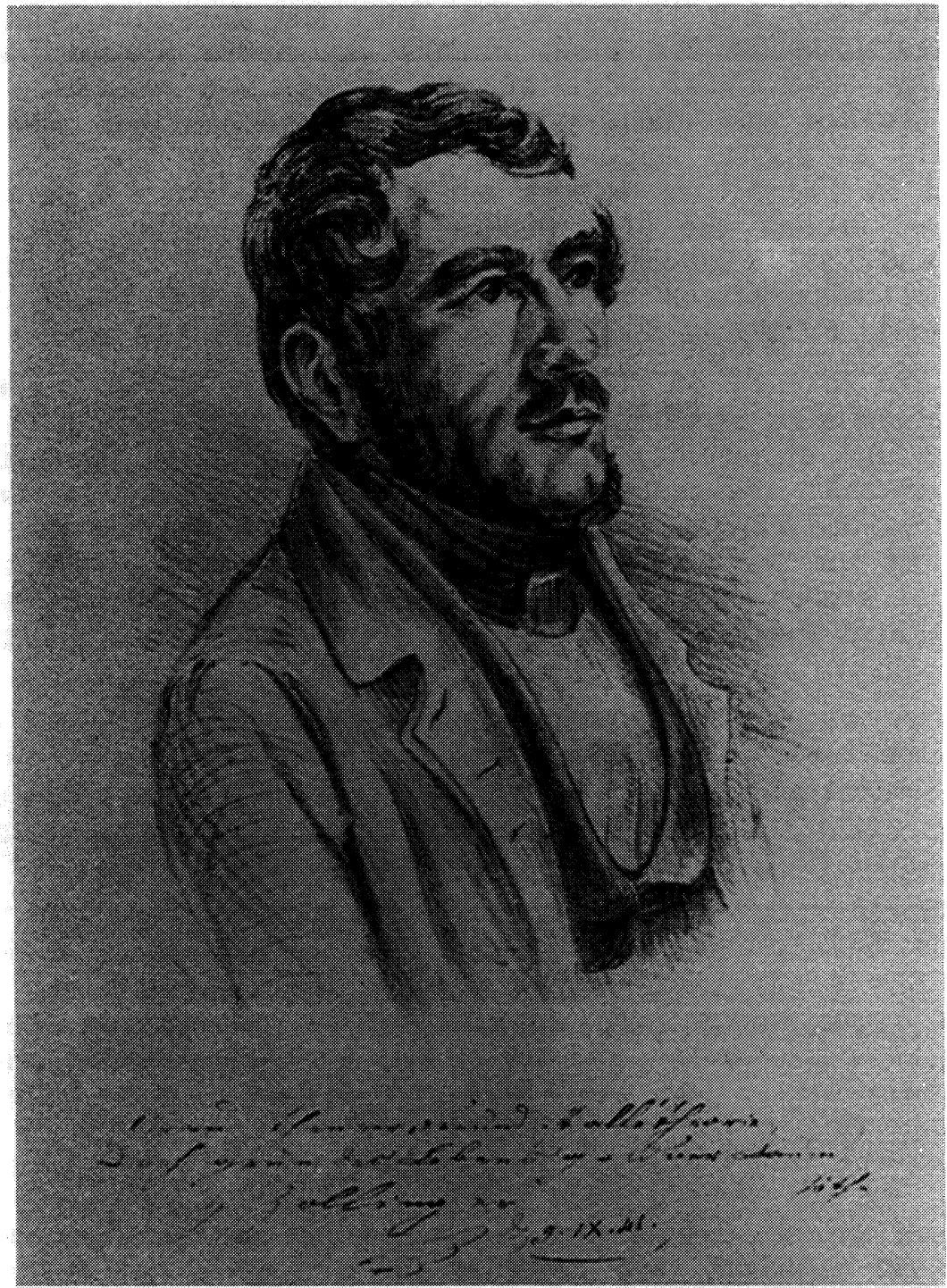

ZOLLINGER IN 1841 
and hurled herself down into her pit. She was the maid [babu] of the late prince. 23

After the self-sacrifices and the burning of the lion-shaped cask, both the great prince and the Pedanda Agung retreat and the gathering begins to break up. Except for the two of us, all hundred thousand odd spectators are satisfied. They are convinced that the souls of the persons who have just been delivered to the flames are now settled in the abode of eternal delights. Every one returns home happily; and those most intoxicated with gaiety are the relatives of the unfortunate Belas. They believe themselves to be henceforth free from calamities, for a powerful arm, that of their respective Bela, will avert such misfortunes as might befall them.

A group of Brahman priests remain near the ashes of the prince, while the remains of the Belas are respectfully guarded by some of their male relatives. They stay there until the following morning, until the fires have cooled down. Then they search among the ashes for the bones which were not consumed by the fire; these bones are deposited in vases, of gold for the prince and for the Belas who had belonged to the nobility [triwangsa] and of silver for the Belas of common origins [sudra]. When this is done they carry the vases with much ceremony into the palace, where they are placed onto a magnificent altar.

While the multitude is leaving, the funeral place is in flames. They are burning the pyramids, the coffins, the calicoes, the decorations, in a word everything which was used in the ceremony, except a few precious materials used in some of the ornaments.

I must say, Sir, that I am overjoyed to be rid of this terrible Brahma! May a wolf munch me for his supper if you will ever catch me again at a spectacle like this.

Ah! There is our dear Made Oka! - "Well, Gentlemen, aren't you impressed with the fortitude of all the Belas? Not one wavered: they all fell beautifully. The court took great pleasure in watching them: but let us go and have dinner." 24

\section{Zollinger (1846)}

Henrich Zollinger (1818-1859), a Swiss biologist attached to the Buitenzorg (Bogor) botanical gardens, made a field trip to Bali and Lombok in 1846 to collect plant specimens and to engage in his favorite hobby: mountain climbing. This visit coincided with the first Dutch military expedition against the Rajas of Bali (i.e., against the Dewa Agung of Klungkung and the Rajas of Buleleng and Karangasem), and Zollinger was to some extent caught up in the

23. In many Asian countries aristocratic children were looked after not by their natural mothers but by trusted female servants. (Indon: babu). Not infrequently, strong personal attachments developed between these children and their maid servants. It is possible that this old woman had a strong affection for the deceased prince and rushed into the flames out of a desire to be reunited with him as soon as possible.

24. Letter VIII in P. Dubois, "Légère Idee de Balie en 1830," Kol. 3087 (The Hague, Algemeen Rijksarchief). 
turmoil. He watched the landing on June 28, 1846 of Dutch colonial troops at Buleleng on Bali's north coast and witnessed the subsequent sacking of the town of Singaraja, where the palace of the Raja of Buleleng was located. He was present at the negotiations in July 1846 between Dutch of ficials and the Rajas of Lombok in Mataram. In addition to collecting plant specimens and climbing Gunung Rinjani on Lombok, Zollinger made a number of astute observations about the people he met, about the trade of the islands, about the customs of the Balinese and Sasak peoples, and so on. 25 These observations provided the material for two articles he published in Dutch journals, namely: "Reis over de Eilanden Bali en Lombok,"26 and "Het Eiland Lombok." 27 In the latter article Zollinger gave a very precise description of the ritual execution of a young Balinese woman:

The Lombok Balinese burn their dead. . . . In Lombok women sometimes allow themselves to be killed after the deaths of their husband. They are not forced to do this. If they decide to die they are given the choice of being burned alive or being stabbed to death. The first option is comparatively rare and is practiced mainly by the wives of Rajas. . . . When a Raja dies a number of women are always burned, even though these women may only be slaves. In Lombok I witnessed a terrible incident of this kind.

A Gusti, who had died in Ampenan, left three wives. The objections of her family notwithstanding, one of them wanted to be stabbed to death in his honor. The woman had no children and was still young and beautiful. People told me that a woman who allows herself to be killed under these circumstances wants to demonstrate her love for her husband. She believes that she will accompany him on his long journey to the gods and that she will become her husband's favorite in the hereafter.

On the day following the Gusti's death the woman who had decided to die took several baths. She dressed herself in her finest clothes and spent the day with her relatives and friends, eating, drinking, chewing betelnut, and praying.... In front of the Gusti's main house two bamboo stages were constructed, about six feet long and just wide enough to accommodate a human body. Underneath these stages some small ditches had been dug to collect the water and blood that was to flow. Inside a smaller building to the left of the Gusti's main house two identical stages had been erected.

At four o'clock in the afternoon a number of men brought the body of the Gusti and placed it onto one of the stages in front of the main house. A priest from Mataram removed the clean linen in which the body was wrapped, and several young men hurried to cover the sexual organs of the deceased with their hands. They

25. The Sasak people are the indigenous inhabitants of Lombok. From the early seventeenth century until the late nineteenth-century Dutch conquest of the island, the Sasaks were ruled by a small Balinese minority living mainly around the courts in West Lombok, in the towns of Mataram and Cakranegara (Alfons van der Kraan, Lombok: Conquest, Colonization, and Underdevelopment 1870-1940 [Singapore: Heinemann Educational Books (Asia), 1980], pp. 1-15).

26. H. Zollinger, "Reis over de Eilanden Bali en Lombok," VBG 26 (1849): 1-15.

27. H. Zollinger, "Het eiland Lombok," Tijdschrift voor Nederlandsch Indie (hereafter TNI) 9 II (1847): 177-205, 301-83. 
washed the body, combed the hair, and covered it with flowers (campaka and kananga). They then brought out a white net. The priest took a silver basin filled with holy water and dropped some flowers into it. He first sprinkled the deceased with the water, and then he threw all the water that was left, through the net, onto the body. The priest next blessed the body and powdered it with a powder made from finely chopped colored rice and flowers. While he performed these acts the priest prayed, chanted, and made all kinds of mystical and symbolic gestures.

A number of women with their arms intertwined carried forward the Gusti's wife. She was dressed only in a piece of white linen. Her hair was decorated with flowers from the Chrysantenium Indicum. She was calm and showed neither fear nor regret. The women set her down in front of her husband's body. The Gusti's wife raised her hands above her head and prayed in silence. A number of women approached her with small bouquets of kembang spatu and other flowers. She accepted the bouquets one by one and briefly placed each of them above her head, holding them between the fingers of her raised hands, before handing them back to the women. Each time the Gusti's wife handed back a bouquet of flowers she turned $a$ bit to the right, so that when she had received eight bouquets she had turned full circle. She again prayed in silence, whereupon she approached the body of her husband which she kissed on the head, the chest, the lower belly, the knees, and the feet. She then resumed her position in front of her husband's body.

One of the women stepped forward and took off her rings, while two other women seized her by the arms. Her brother (in this particular instance her adoptive brother) placed himself in front of her and asked in a low voice whether she was still prepared to die. When she nodded in consent he asked her to forgive him for having to kill her. Then, suddenly, he grabbed his kris and stabbed her in the left side of the chest. The wound, however, was not very deep and the woman remained standing. The brother then threw his kris to the ground and ran away. Another man now stepped forward. He at once pushed his kris up to the hilt into the poor woman's chest whereupon she collapsed without uttering a sound. The women placed her onto a mat and rolled and pressed the body to make the blood flow as quickly as possible. But after a while she was still alive. The man again stepped forward and stabbed the woman in the back between the shoulder blades. When she had at last expired the women placed the body onto the stage next to her husband's.

The ceremony which had taken place for the man was now carried out for the woman as well. When it was finished, the two bodies were covered with resin and with various cosmetic substances; they were wrapped in white linen, carried away, and placed onto the two stages inside the small building to the left of the main house.

The native spectators who were gathered around me did not seem to see anything offensive in this awful butchery. They laughed and talked as if it was nothing. The man who had at long last killed the woman wiped his kris calmly and placed it in its sheath, just as if he had just butchered some kind of animal. 
110

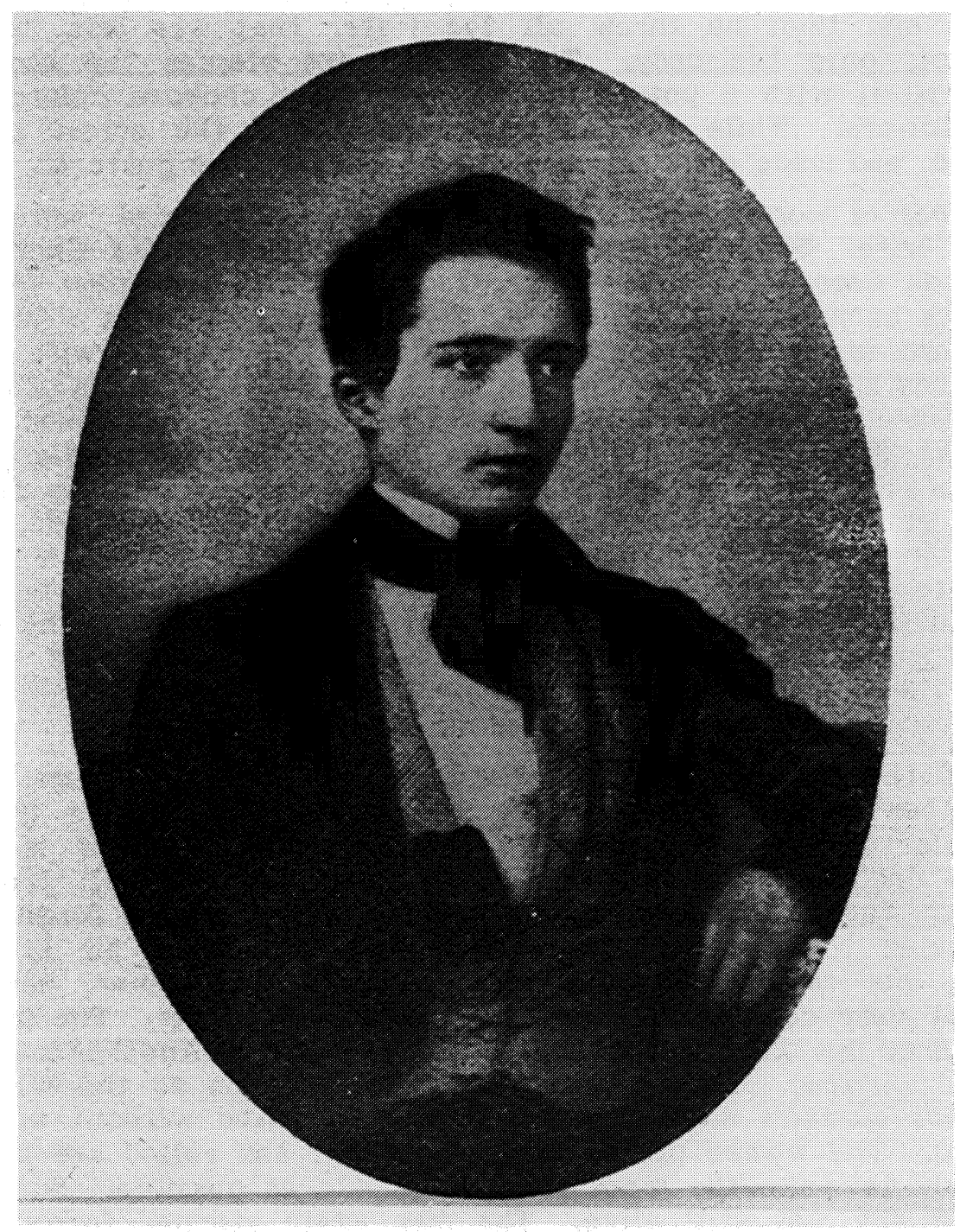

HELMS IN 1846 
People told me that only the wives of notables allow themselves to be burned because this is much more expensive than to be simply stabbed to death. When women are burned they construct a very high bamboo tower. After many involved ceremonies the women ascend these towers. And when the fire is extremely hot they jump from the tower. According to Mr. K., 28 they do not suffer because, he says, they are asphyxiated during the fall. In any case, the fires into which these women jump burn so fiercely that death is bound to follow very quickly. 29

\section{Helms (1847)}

Ludvig Verner Helms, a Danish adventurer, set sail for Bali in September 1846 to join his countryman Mads Lange, who maintained an extensive commercial establishment on the island. From April 1847 to June 1849 the young Helms worked as a secretary, clerk, and supercargo in Lange's factory in Kuta in the South Balinese principality of Badong. Like Zollinger, Helms, too, became involved in the conflict between the Dutch colonial government and the Rajas of Bali (i.e., the Dewa Agung of Klungkung and the Rajas of Buleleng and Karangasem). As an employee of Lange he participated to some extent in the important mediating role Lange played in this war. For instance, in June 1849, shortly before he left Bali to look for gold in California, Helms conducted a party of envoys from the Rajas of Badong and Tabanan to Colonel van Swieten, the commander of the Dutch military expedition encamped at Padang Cove in Karangasem, East Bali. In 1882, when at last his travels were over, Helms published his memoirs, entitled: Pioneering in the Far East. In this work he gives an account of the cremation of Dewa Manggis, Raja of Gianyar, a ceremony at which three women were sacrificed. This cremation, which Helms witnessed in the company of Lange, the German orientalist Friederich, and several other Europeans, took place in the town of Gianyar on December 20, 1847.

But a tragedy was enacted during my stay in Bali, which most profoundly impressed me; and it was the more terrible because, though enacted in the name of religion, it was not merely the fervour of the fanatic that gave the victims strength to play their strange parts, but that human affection which is common to us all. I am alluding to the immolation of women on the funeral pile of their husbands.

28. "Mr K" refers to George Pocock King, the English merchant (born in Bengal) who, attracted by the profitable Lombok-China rice trade, established himself on the island in 1835. He became the arch-rival of the Danish trader, Mads Lange, who had arrived in Lombok about a year earlier. In the late 1830s this rivalry assumed the form of open warfare. During the struggle between two Balinese dynasties, Mataram and Karangasem (1837-38), King and Lange supported opposing sides with ships, artillery, and auxiliary troops. In 1838 King's side, the Mataram dynasty, proved victorious, which meant that Lange had to flee the island. In early 1839 Lange established himself in Badong, South Bali, where he maintained a flourishing trading establishment until his death in 1854 . King stayed in Lombok until about 1856 when he left the island for an unknown destination. A. K. Nielsen, Mads Lange til Bali (Kobenhavn: Gyldendals, 1944), pp. 31-47; Henk Nordholt, "The Mads Lange Connection. A Danish Trader on Bali in the Middle of the Nineteenth Century: Broker and Buffer," Indonesia 32 (1981): $17-47$.

29. Zollinger, "Reis over de Eilanden," pp. 345-49. 
While I was at Bali one of these shocking sacrifices took place. The Rajah of the neighbouring State died on 20 December 1847; 30 his body was burned in great pomp, three of his concubines sacrificing themselves in the flames. It was a great day for the Balinese. It was some years since they had had the chance of witnessing one of these awful spectacles, a spectacle that meant for them a holiday with an odour of sanctity about it; and all the reigning Rajahs of Bali made a point of being present, either personally or by proxy, and brought large followings.

It was a lovely day, and along the soft and slippery paths formed by the embankments which divide the lawn-like terraces of an endless succession of paddy-fields, groups of Balinese, in festive attire, could be seen wending their way to the place of burning. Their gay dresses stood out in bright relief against the tender green of the ground over which they passed. They looked little enough like savages, but rather like a kindly festive crowd bent upon some pleasant excursion. The whole surroundings bore an impress of plenty, peace and happiness, and, in a measure, of civilization. It was hard to believe that within a few miles of such a scene, three women, guiltless of any crime, were, for their affection's sake, and in the name of religion, to suffer the most horrible of deaths, while thousands of their countrymen looked on.

But already the walls which surround the palace of the King of Gianyar are in sight. Straight avenues, up the sides of a terraced hill, lead to the kraton, or palace; and, higher still, on the centre of an open space, surrounded by a wooden rail, a gaudy structure with gilded roof, rising on crimson pillars, arrests the attention. It is the spot where the burning of the dead man's body is to take place. Upon closer inspection the structure is seen to rest upon a platform of brick-work four feet high, upon which is a second floor, covered with sand. In the centre stands a wooden image of a lion, gorgeous with purple and golden trappings. The back is made to open, and is destined to receive the body of the King for burning. The entire building is gaudily decorated with mirrors, china plates, and gilding. 31

Immediately adjoining this structure is a square surrounded by a wall four feet high, the whole of which space was filled with a fierce, bright fire, the fatal fire which was to consume the victims. At an elevation of twenty feet a light bamboo platform is connected with this place, a covering of green plantain stems protecting it against fire. The centre of this bridge supports a small pavilion, intended to receive the victims while preparing for the fatal leap.

30. This is incorrect. Dewa Manggis was cremated on December 20, 1847; according to Friederich, the Raja had died about forty days earlier. R. T. Friederich, "Een feest in de hoofdplaats van het rijk Gianjar op het eiland Bali," TNI 11 I (1849): 425 .

31. The scene Helms observed in Gianyar in 1847 clearly had much in common with that witnessed by Dubois about eighteen years earlier in Badong. Helms' "gaudy structure" and his "wooden image of a lion" conjure up much the same picture as Dubois' "pavilion" and "lion-shaped cask." 
The spectators, who, possibly, did not number less than 40,000 or 50,000, occupied the space between these structures and the outer wall, inside which a number of small pavilions had been erected for the use of women. This space was now rapidly filling, and all eyes were directed towards the kraton whence the funeral procession was to come. Strange to say, the dead King did not leave his palace for the last time by the ordinary means. A corpse is considered impure, and nothing impure may pass the gateway. Hence, a contrivance resembling a bridge had been constructed across the walls, and over it the body was lifted. This bridge led to the uppermost storey of an immense tower of a pagoda shape, upon which the body was placed. 32

This tower, called the bade, was carried by five hundred men. It consisted of eleven storeys besides three lower platforms, the whole being gorgeously ornamented. Upon the upper storey rested the body, covered with white linen, and guarded by men carrying fans.

The procession marching before the bade consisted first of strong bodies of lance-bearers, with music at intervals; then a great number of men and women carrying the offerings, which consisted of weapons, elothing, ornaments, gold and silver vessels containing holy water, siri-boxes, fruit, meat-dishes, boiled rice of many colours and, finally, the horse of the deceased, gaily caparisoned; then more lance-bearers and some musicians. These were followed by the young King, the Dewa Pahang, with a large suite of princes and nobles. After them came the pandita [i.e., the Pedanda Agung], or high priest, carried upon an open chair, round which was wrapped one end of a cloth, made to represent a huge serpent, painted in white, black and gilt stripes, the huge head of the monster resting under the pandita's seat, while the tail was fastened to the bade, which came immediately after it, implying that the deceased was dragged to the place of burning by the serpent.

Following the large bade of the dead King came three minor and less gorgeous ones, each containing a young woman about to become a sacrifice or Bela. The victims of this cruel superstition showed no sign of fear at the terrible doom now so near. Dressed in white, their long black hair partly concealing them, with a mirror in one hand and a comb in the other, they appeared intent only upon adorning themselves, as though for some gay festival. The courage which sustained them in a position so awful was indeed extraordinary, but it was born of the hope of happiness in a future world. From being bondswomen here, they believed they were to become the favourite wives and Queens of their late master in another world. They were assured that readiness to follow him to a future world, with cheerfulness and amid pomp and splendour, would please the unseen powers, and induce the great god Siva to admit them without delay to Swarga Surya, the Heaven of Judra.

32. Oosterwijck, too, had observed the unusual way in which the Balinese brought the body out of the palace. However, in Oosterwijck's account the Queen's body was taken through a hole in the palace wall, while in Helms' description the Raja's body was carried over the wall. 


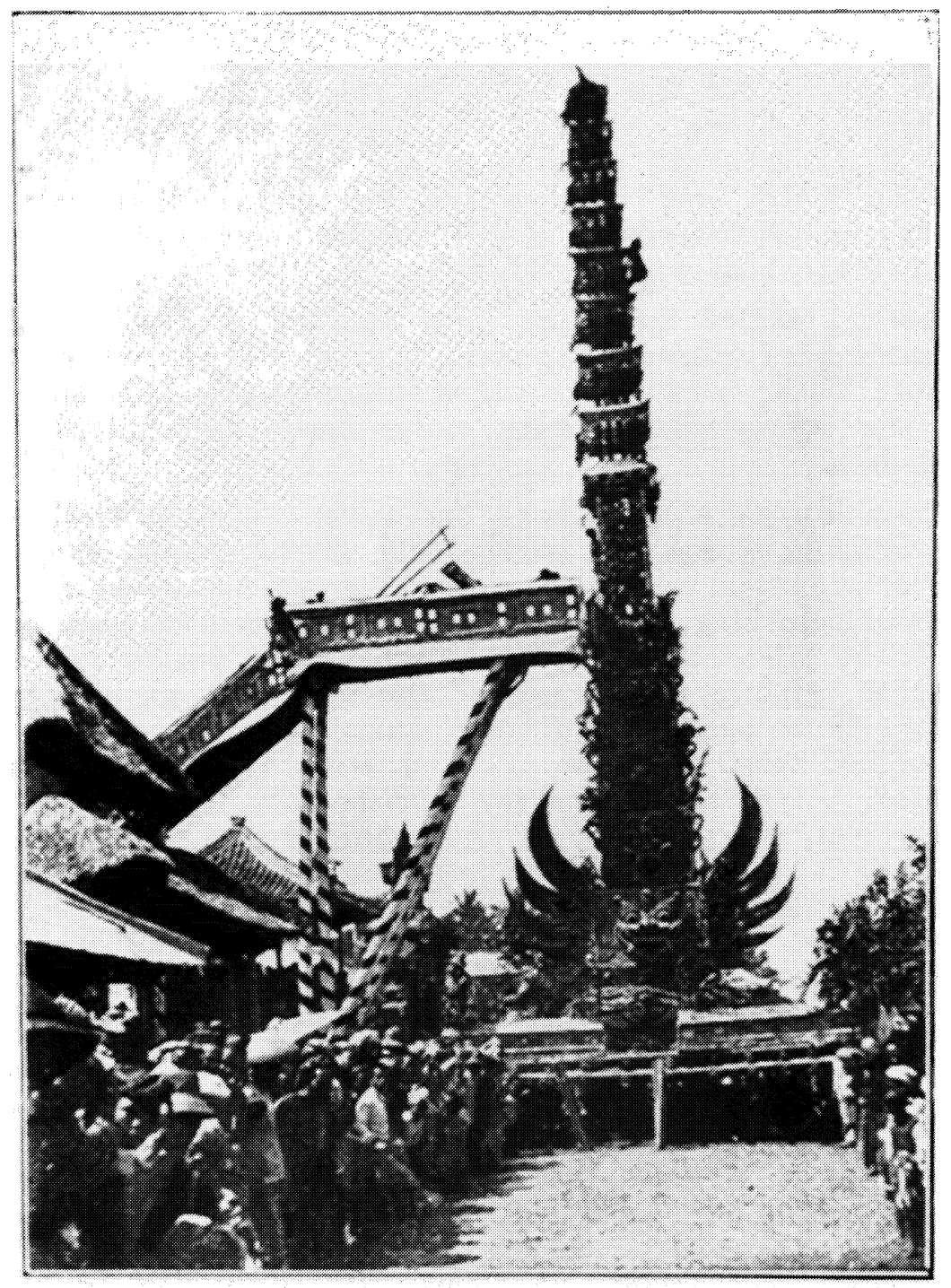

THE BODY IS PLACED IN THE BADE (1920'S) 
Round the deluded women stood their relatives and friends. Even these did not view the ghastly preparations with dismay, or try to save their unhappy daughters and sisters from the terrible death awaiting them. Their duty was not to save but to act as executioners; for they were entrusted with the last horrible preparations, and finally sent the victims to their doom.

Meanwhile the procession moved slowly on, but before reaching its destination a strange act in the great drama had to be performed. The serpent had to be killed, and burned with the corpse. The high priest descended from his chair, seized a bow, and from the four corners of the compass discharged four wooden arrows at the serpent's head. It was not the arrow, however, but a flower, the campaka, that struck the serpent. The flower had been inserted at the feathered end of the arrow, from which, in its flight it detached itself, and by some strange dexterity the priest so managed that the flower, on each occasion, hit its mark, viz. the serpent's head. The beast was then supposed to have been killed, and its body having been carried hitherto by men, was now wound round the priest's chair and eventually round the wooden image of the lion in which the corpse was burned. 33

The procession having arrived near the place of cremation, the bade was thrice turned, always having the priest at its head. Finally it was placed against the bridge which, meeting the eleventh storey, connected it with the place of cremation. The body was now placed in the wooden image of the lion; five small plates of gold, silver, copper, iron and lead, inscribed with mystic words, were placed in the mouth of the corpse; the high priest read the Vedas, and emptied the jars containing holy water over the body. This done, the faggots, sticks striped in gold, black, and white, were placed under the lion, which was soon enveloped in flames. This part of the strange scene over, the more terrible one began.

The women were carried in procession three times round the place, and then lifted onto the fatal bridge. There, in the pavilion which has been already mentioned, they waited till the flames had consumed the image and its contents. Still they showed no fear, still their chief care seemed to be the adornment of the body, as though making ready for life rather than for death. Meanwhile, the attendant friends prepared for the horrible climax. The rail at the further end of the bridge was opened, and a plank was pushed over the flames, and attendants below poured quantities of oil on the fire, causing bright, lurid flames to shoot up to a great height. The supreme moment had arrived. With firm and measured steps the victims trod the fatal plank; three times they brought their hands together over their heads, on each of which a small dove was placed, and then, with body erect, they leaped into the flaming sea below, while the doves flew up, symbolizing the escaping spirits.

33. In Dubois' account there is no mention of a ritual involving a serpent (nagabanda). This was not an oversight, but was due to differences in ritual between the cremation of Wesiyas (title: Gusti) and Ksatriyas (title: Dewa). The serpent image was used only at the cremations of princes belonging to the Ksatriya caste. (Friederich, "Een feest in de hoofdplaats," p. 427.) 
Two of the women showed, even at the very last, no sign of fear; they looked at each other, to see whether both were prepared, and then, without stooping, took the plunge. The third appeared to hesitate, and to take the leap with less resolution; she faltered for a moment, and then followed, all three disappearing without uttering a sound. 34

This terrible spectacle did not appear to produce any emotion upon the vast crowd, and the scene closed with barbaric music and firing of guns. It was a sight never to be forgotten by those who witnessed it, and brought to one's heart a strange feeling of thankfulness that one belonged to a civilization which, with all its faults, is merciful, and tends more and more to emancipate women from despotism and cruelty. 35

\section{E. Friederich (1847)}

In early 1846 the then Governor-General of the Netherlands Indies, J. J. Rochussen, decided on a military campaign against several of the Rajas of Bali (i.e., the Dewa Agung of Klungkung, the Rajas of Buleleng and Karangasem) in an attempt to bring that island more firmly in the Dutch sphere of interest. When preparations for the military expedition were in progress Batavia discovered that, despite its close proximity to Java, very little was known about Bali. To rectify this it was decided to send an expert to the island. The choice fell upon Dr. R. Th. Friederich, a German Orientalist and linguist, specialized in Hinduism and with a good knowledge of Sanskrit. Friederich duly arrived in Bali in July 1846 and found accommodation with the hospitable Mads Lange in Kuta (Badong), where, about a year later, he was joined by the young Helms. During the two-year period he lived in Bali, Friederich worked closely with a number of Balinese priests; he learned the language and gathered a great deal of material on Balinese culture and religion. Not long after his return to Java in August 1848 Friederich published the first really scholarly account of Bali, entitled: "Voorlopig Verslag van het Eiland Bali."36 In this account Friederich described the 1847 Gianyar sacrifices he witnessed in the company of Lange, Helms, and several other Europeans:

On 20 December 1847 the prince of Gianyar, Dewa Manggis, was burnt. ... The three women (concubines) who were to become Belas came behind the body of the prince. They were taken to the place of cremation in procession, seated in the highest stories of their bades. These bades, which had only three stories, were carried by a large group of men. After the body of the prince had arrived at the place of cremation, the three Belas, sitting in their bades, were conducted in procession to the three fires.

34. Helms' description gives the impression that these three women jumped into a single blazing pit. This, however, was not the case. As can be learned from Friederich's account, the three Belas were sacrificed in exactly the same way as described by Dubois--they jumped down into separate pits.

35. L. V. Helms, Pioneering in the Far East (London: Allen, 1882), pp. 57-65.

36. R. T. Friederich, "Voorlopig Verslag van het Eiland Bali," VBG 22 (1849): 1-63, and 23 (1850): 1-57. 
Their bades were turned around three times before being carried round the whole place of cremation. The women were then lifted from their bades and carried up the steps of the places constructed for their sacrifices. These places consisted of squares of masonry three feet high, filled with combustibles which had been burning since the morning and which threw out a scorching heat. Behind these furnaces stood bamboo structures shaped like bridges. These structures were of the same width as the squares of masonry; they were about forty feet long and between sixteen and eighteen feet high. Bamboo steps led up to them in the rear. In the center of these bridges stood small houses which afforded final resting-places to the victims. The sides of the bamboo structures nearest to the fires were protected by walls of wet pisang-stems. Upon the bridges lay planks smeared with oil. These planks were pushed out over the fires when the women were ready to jump down. There were doors at the end of the bridges which were removed only at the last moment.

The victim sat in the little house on the bridge, accompanied by a female priest and by her relatives. They all spoke to her of the happiness which she would soon enjoy. She groomed herself; combed her hair, looked into her mirror, rearranged her garment, in short she arrayed herself as if she was going to a party. Her dress was white, her breasts were covered with a white slendang, and her hair had been made up in such a way that it would continue to hang down during the jump into the fire. When fire had almost consumed the body of the prince, the three Belas readied themselves; they glanced at each other to convince themselves that they were all prepared. This was not a glance of fear, but of impatience and it seemed to express the wish that they might leap at the same moment. When the doors on the bridges had been opened and when the oiled planks had been pushed out, each victim took her place on her plank; each made three nyembahs by joining the hands above the head and each received a small dove (titiran) upon the head from one of the bystanders. As soon as the doves flew away, symbolizing the escaping souls, they leaped down. At the moment the women leaped down the attendants appointed to watch the fire poured upon it a quantity of oil and arak so that it flared up to a height of eight feet. There was no cry during the fall, no cry from the fire; they must have suffocated at once. One of the Europeans present [Helms?] who succeeded in pushing through the crowd to the fire saw one of the women only seconds after the jump. She was dead and the body's movements were caused merely by the combustions of the materials cast upon the flames. On other occasions, however, Europeans have heard cries uttered in leaping and in the first moments afterwards.

During the whole time, from the burning of the prince till the jump of the victims, the air resounded with clangor and noise of the numerous bands of music. The soldiers had drawn up outside the square and contributed to the noise by firing their muskets. In addition, some small cannon were discharged. There was not one among the fifty thousand Balinese present who did not show a merry face; no one seemed filled with repugnance or disgust except a few Europeans, whose only desire was to see an end of such barbarities. 37

37. Friederich, "Voorlopig Verslag" (1850): 11-12. 


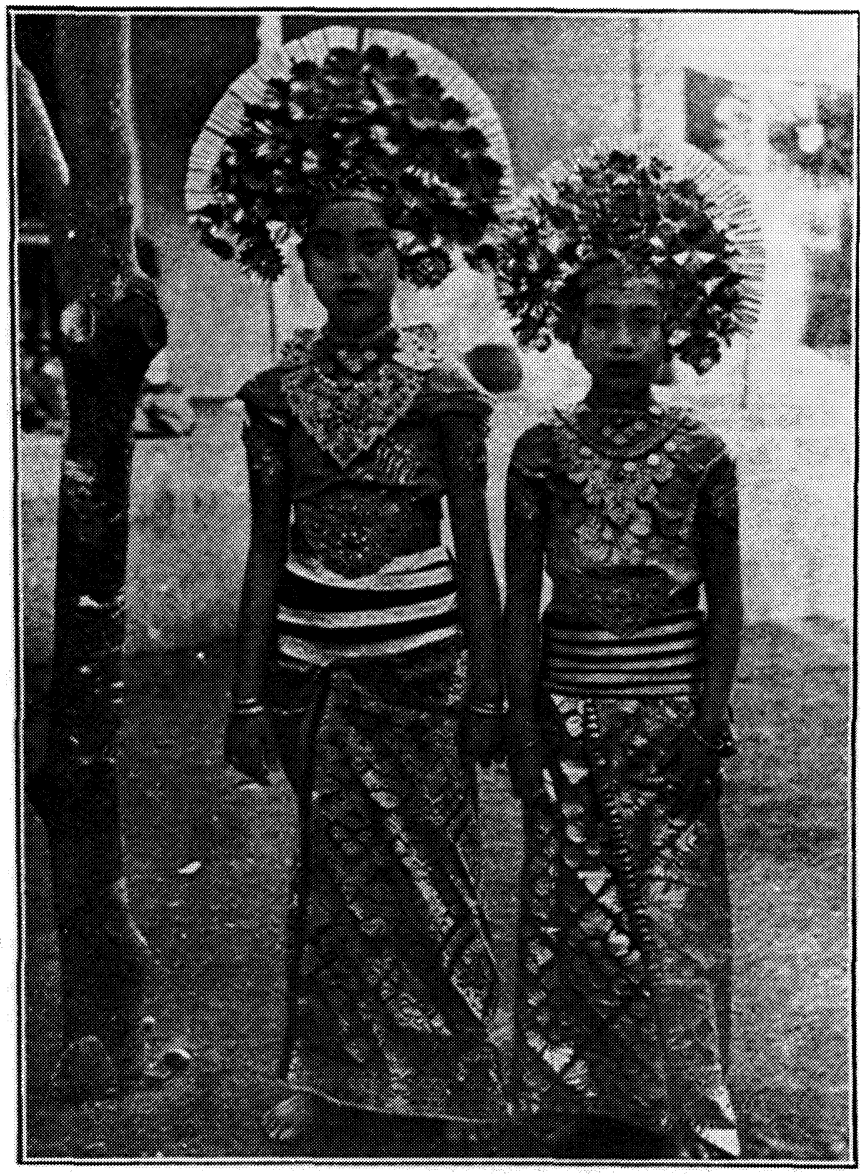

TWO YOUNG PALACE WOMEN DRESSED UP FOR THE CREMATION (1920'S) 


\section{Conclusions}

The five accounts presented above provide only a limited and fleeting impression of the reality of human sacrifice in Bali. Due to the remoteness of the island during most of modern history, Europeans, especially Europeans of some literary ability, were but rarely present at the great cremation ceremonies, and, where they were present, many details of the complicated ritual surrounding the sacrifices necessarily escaped their attention. But while the historical record is extremely sketchy and piecemeal, it is possible nonetheless to draw certain conclusions from it. The record shows quite clearly, for instance, that mesatia belonged to the realm of the court rather than to that of the village, that it belonged to Bali's "great" tradition rather than to its "little" tradition. The record confirms what Gusti Made Oka told Dubois in 1829, namely: that human sacrifice was practiced only at the great cremation ceremonies of Kings, Rajas, and princes, the rich and powerful, and not at the far less elaborate cremations of poor Gustis and peasants.

Although the vast majority of Bali's population were merely spectators who did not themselves practice mesatia, the phenomenon was not particularly rare. During the two-year period from July 1846 to August 1848 there were, apart from the human sacrifices at Gianyar in December 1847, at least five instances of mesatia in Balinese-ruled Lombok, each of which involved the sacrifice of between four and seven women. Similarly, during the thirty-year period from 1820 to 1850 there were in the principality of Badong alone (i.e., in only one of the eight principalities into which Bali was divided) a total of seven instances of mesatia, each of which involved the sacrifice of between one and nine women. ${ }^{38}$ On the basis of these figures it would seem reasonable to assume that in the nineteenth century a cremation ceremony, at which between one and nine women were sacrificed, occurred on average at least once, and perhaps twice, a year somewhere in Bali or in Lombok.

The record also gives some indication of the social identity of the victims. The sacrifice in 1633 of twenty-two women at the cremation of a Queen (Oosterwijck), the sacrifice in 1840 of one woman at the cremation of a prince and two princesses (Schuurman), the sacrifice in 1829 of the old babu of Gusti G'de Ngurah Pamacutan (Dubois), the sacrifice in 1847 of three concubines (gundik) at the cremation of Dew a Manggis 39-all this suggests very strongly that the victims were of ten not the official wives, the widows, of the deceased. If the Belas were not normally the official wives of the deceased, who, then, were they?

Oosterwijck clearly identifies the victims as female slaves (slavinnen), while Friederich, too, asserts that most of the victims were slaves, 40 Many of these female slaves, no doubt, had been the concubines of the deceased Rajas and princes, but apparently, this was not always the case. Dubois reports, for instance, that one of the Belas sacrificed in 1829, almost certainly a slave, was an old, white-haired woman who had been the babu of the deceased prince. While the great majority of victims were almost certainly slaves (concubines or other types of servants), this again was not always the case. Dubois' statement that the bones of Belas of noble origin (triwangsa) were

38. Ibid., pp. 13-14.

39. Ibid., p. 8.

40. Ibid., p. 11. 
placed in golden vases, while the remains of those of common origin (sudra) were deposited in silver vases, suggests that, at least occasionally, high-status women, the official wives, the sisters or other relatives of the deceased, were among the victims. The Belas, then, were not recruited from a single social category: frequently they were slaves, but sometimes they were women of high status; frequently they were concubines, but sometimes they were servants of a different type. In fact, the only thing they had in common was their sex: the victims were invariably women. This means, then, that mesatia should be characterized not simply as "widow-burning," but as human sacrifice, or perhaps more precisely, as women's sacrifice.

The historical record further provides some insights into the puzzling question of Bela motivation. Our observers are unanimous in claiming that mesatia was not a forced type of human sacrifice, that the victims were not sacrificed against their will, but that they went to their deaths voluntarily. Oosterwijck, for instance, states quite specifically: "they all jump into the fire of their own free will"; Dubois comments on the "serenity and ecstatic expectation" of the Belas; Zollinger claims "they are not forced [to sacrifice themselves]"; while both Helms and Friederich comment on the victims' courageous bearing and the apparent eagerness with which they jumped down into the blazing pits. So, why did they do it?

The sacrifices only appeared to be voluntary because, in reality, quite severe psychological and social pressures were brought to bear on the women. The psychological pressures were largely religious in nature. According to Zollinger, Helms, and Friederich, the women were influenced in their decision to offer themselves for sacrifice by their religious convictions, by their no-doubt firmly held belief that this would ensure immediate entry into Heaven (Swarga), where they would enjoy eternal life and happiness. And, according to Oosterwijck, Dubois, Helms, and Friederich, religion played a vital role also in sustaining the victims in their decision. All these observers testify that in their final moments the Belas were accompanied by female priests who, apart from carrying out certain rituals, no doubt sought to strengthen the victims in their resolve by reminding them of the happiness which awaited them in the hereafter.

Severe social pressures were exerted by the court environments (puri) to which the women belonged. Both Oosterwijek and Friederich mention that as soon as women declared their intention to sacrifice themselves they became the centers of attention. They were regarded as holy beings, their feet were no longer allowed to touch the ground, people made offerings to them, they were carried everywhere, and all their wishes and desires were fulfilled. From the moment they declared themselves until the day of the sacrifice, which was often quite a long time, the women, and especially of course the slaves among them, enjoyed more honor, prestige, and status than they had ever experienced before. ${ }^{41}$ It goes without saying that all this public adulation made it extremely difficult for the women to retract their decision.

Pressures were exerted also by the victims' families. All our observers testify that fathers, brothers, and other relatives of the Belas were closely involved in the sacrifices. Family involvement was not limited to assisting with the cremation of the victims, but extended even to the actual executions. Zollinger describes how the brother of a victim bungled the execution and both Dubois and Friederich mention that, in cases where Belas lost courage

41. Ibid. 
at the last moment and hesitated to take the last step, a relative, usually a father or a brother, would be on hand to "lift the plank." The families of the victims clearly wanted the sacrifices to take place, and they encouraged the women to persevere. Again, it goes without saying that this family pressure made it very difficult indeed for the women to retract their decision even if they had wished to do so.

But why did the families of the victims behave in this way? According to Dubois, they were motivated by religious beliefs. He describes how the relatives of the Belas left the cremation site "intoxicated with gaiety" because, he suggests, "they believed they now had a powerful advocate in Heaven, an advocate who could be relied upon to watch over them and avert all misfortunes." Friederich, however, points to the role played by material motives. He suggests that the male relatives of the Belas received certain rewards from the courts, like a rice field (sawah), an appointment as pambekel, and the like.42 It seems highly probable that both these factors influenced the Bela families.

And finally, the historical record gives some indication also of what mesatia meant to the Balinese people. To all Balinese, the peasants and the lords, the villages and the courts, the sacrifice of one or more women was the climax of a great religious festival, a festival which, in sharp contrast to European funerals, was essentially happy in nature. All our observers were struck by the festive atmosphere, by the apparent absence of revulsion or grief. But while to all Balinese mesatia was part of an essentially happy religious festival, it clearly had additional significance for the courts, for the relatives of the deceased King or Queen, Raja or prince. For the courts the sacrifice of a number of women was an important way of honoring the deceased; the sacrifices were meant to please the deceased; they were intended to ensure that in the hereafter the deceased would be able to enjoy the company and services of some of the women who had served him/her in life. From the point of view of the courts, sacrificing a number of women who, as slaves or as subordinate members of the family, had "belonged" to the deceased, was not essentially different from sacrificing some of his/her personal possessions. The chair and the couch which, according to Oosterwijek, were burnt at the cremation of the Queen; the mirrors and utensils which, according to Friederich, were destroyed at the cremation of Dewa Manggis--these acts were also intended to make life more pleasant for the deceased in the hereafter. In the final analysis, the practice of mesatia shows quite clearly that at the Balinese courts women, especially of course those of slave status, were regarded simply as property.

42. Ibid. 